Wireless capsule endo bronchoscopy

David M. Baratz, MD

Sandra Till, DO

Banner Good Samaritan Medical Center

Phoenix, AZ

Case Presentation

\title{
History of Present IIIness
}

A 67 year-old man presents 10 days after swallowing a capsule endoscopy camera that was never retrieved. The wireless capsule was swallowed asymptomatically for evaluation of heme positive stools after negative upper and lower endoscopies. Patient noted that the evening after swallowing the camera he developed mild shortness of breath and cough. The cough and shortness of breath were persistent and worsened while lying down and when moving positions. He denied prior issues with swallowing or aspiration.

\section{Review of Systems}

Negative other than what is noted above.

\section{$\mathrm{PMH}, \mathrm{SH}$, and $\mathrm{FH}$}

Past medical history: coronary artery disease, peripheral vascular disease, hyperlipidemia

Surgical history: femoral-popliteal bypass, previous shoulder and back surgery Social history: 1 pack/day of cigarettes for 50 years, prior alcohol usage but not current, no illicit drugs

Family history: no pulmonary diseases

\section{Physical Exam}

Vital signs: temperature $36.7^{\circ} \mathrm{C}$, heart rate 86 beats per minute, respiratory rate 15 breaths/min, blood pressure 156/69, and oxygen saturation $97 \%$ while breathing room air

Lungs: bilateral wheezing with left greater than right.

Otherwise examination was normal.

\section{Radiography}

The admission chest $\mathrm{x}$-ray is shown in figure 1. 


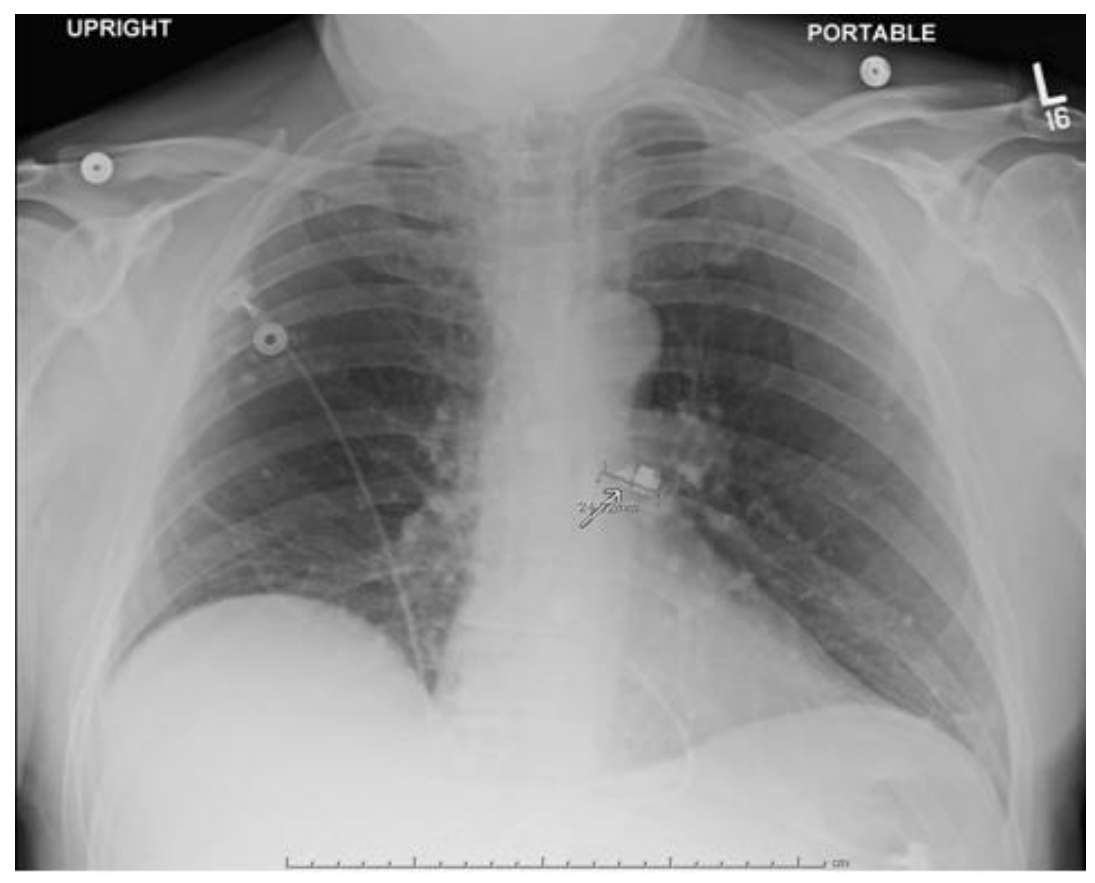

Figure 1. Chest x-ray with capsule in left main bronchus (arrow).

A thoracic CT scan is shown in Figure 2.

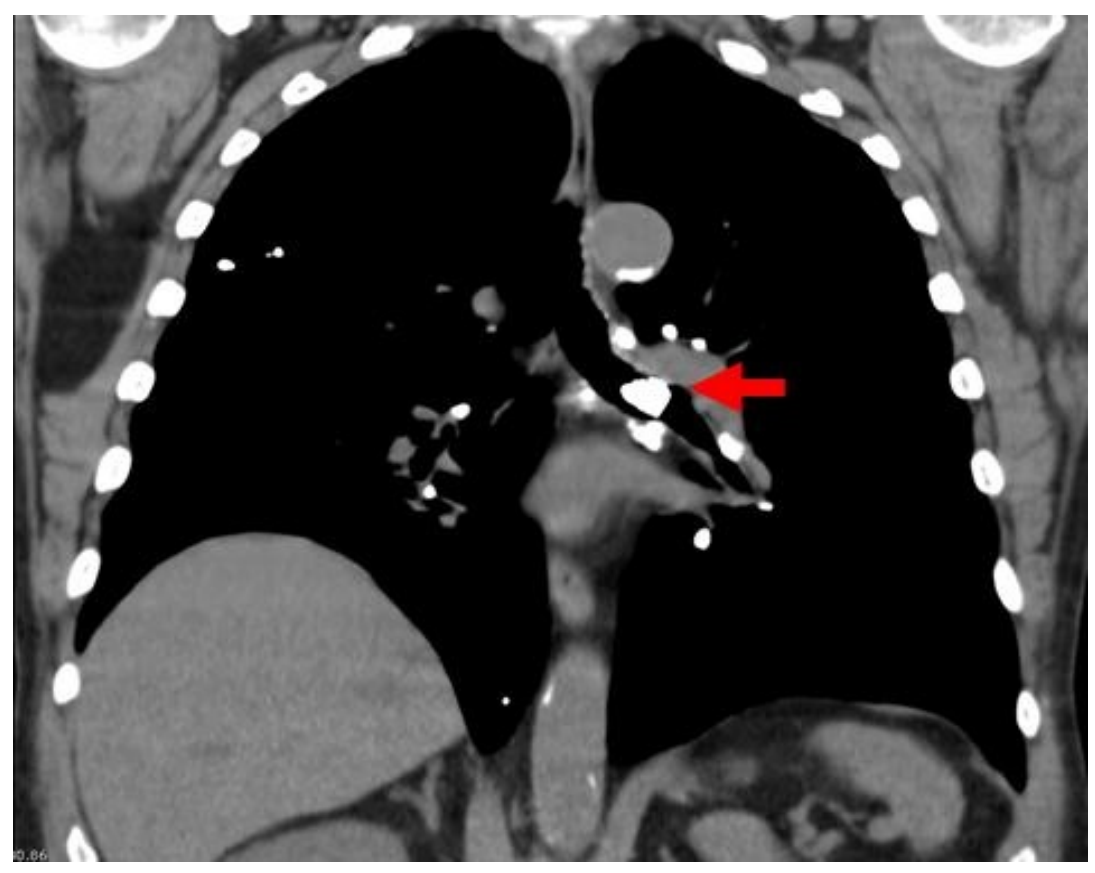

Figure 2. Thoracic non-contrast CT scan with capsule in left main bronchus (arrow). 
Bronchoscopy was performed under general anesthesia using a laryngeal mask airway (LMA). Bronchoscopic examination revealed a white capsule lodged in left main bronchus (Figure 3).

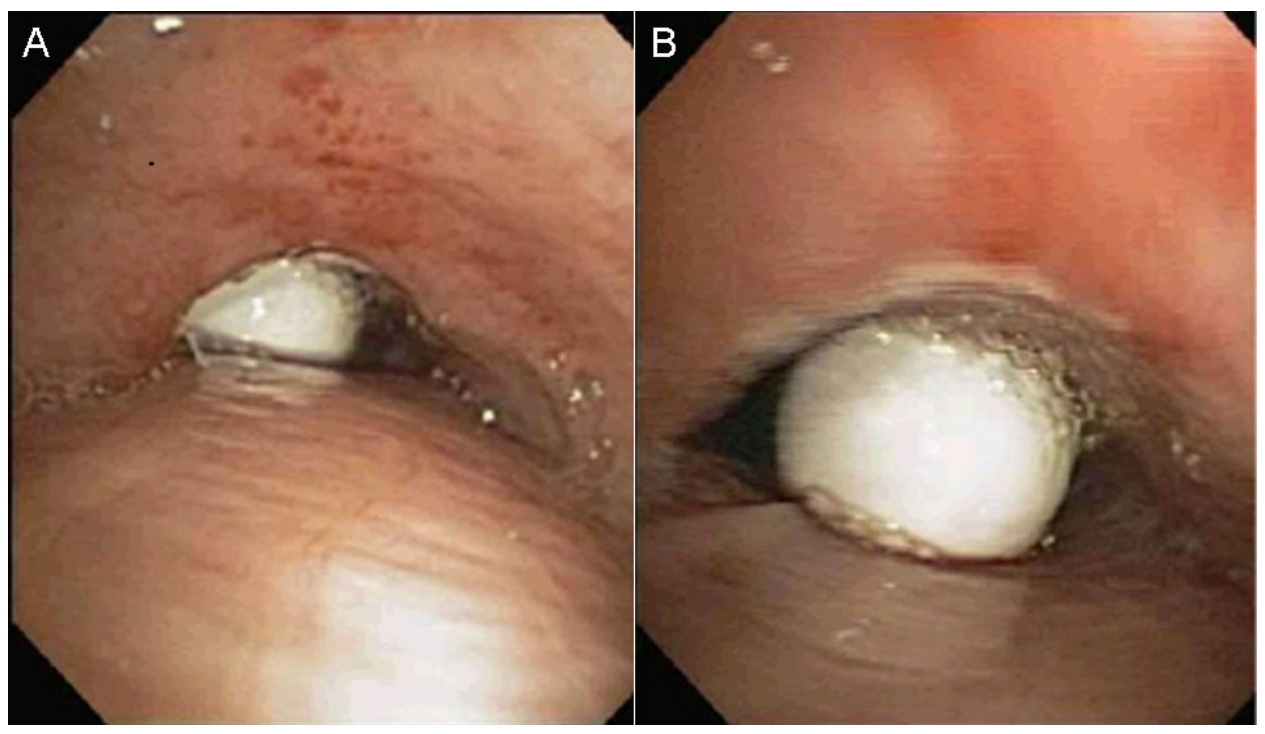

Figure 3. Bronchoscopy with capsule in left main bronchus.

A mesh basket was used to retrieve of the capsule from the left main bronchus, but in the carina the capsule slipped out of the basket. Attempts to use snare and retrieval forceps failed due to the slippery plastic housing covering the capsule. The mesh basket was used again with capture of the capsule. Once the capsule was retrieved, the LMA was removed to avoid en bloc damage to the vocal cord while removing the capsule. The LMA was then reinserted for continued ventilation after the capsule had been obtained.

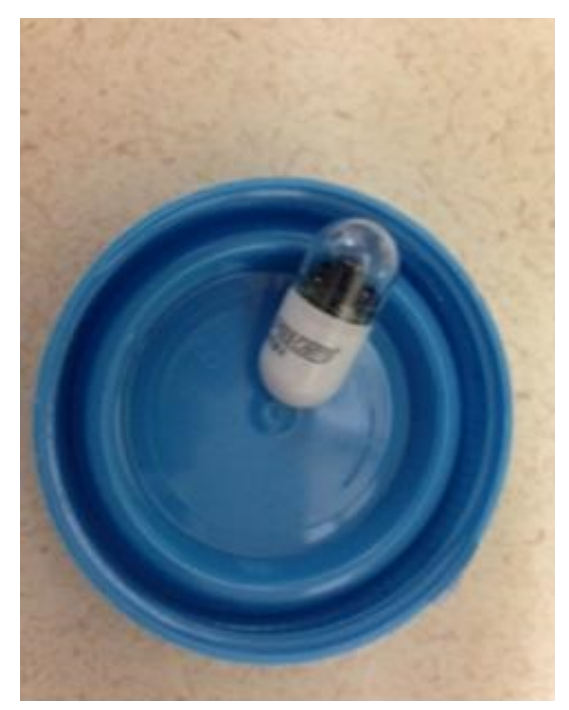

Figure 2. Intact capsule after removal. 


\section{Literature Review}

Capsule endoscopy has been available since 2001 and is used for the evaluation of obscure gastrointestinal bleeding and iron deficiency anemia. The retention rate is $1-2 \%$, with capsules typically found in diverticula, hernias, or other bowel abnormalities (1-3). It is reported that approximately $2 \%$ of patients will have difficulty or inability to swallow the capsule. Review of 13 available cases of aspiration of wireless endoscopy capsules revealed that about $50 \%$ of the time capsules are spontaneously expulsed by coughing, and the other half requiring bronchoscopic intervention for removal (Table 1).

Table 1. Summary of cases with aspirated wireless endoscopy capsules.

\begin{tabular}{|c|c|c|c|c|}
\hline Case & $\begin{array}{c}\text { Difficulty } \\
\text { swallowing } \\
\text { capsule? }\end{array}$ & Symptoms & Removal & Age \\
\hline Schneider (9) & Yes & Cough & Cough & 64 \\
\hline Nathan (7) & No & None & Cough & 93 \\
\hline Buchmaster (5) & No & Dyspnea with exertion & Flexible bronchoscopy & 74 \\
\hline Choi (4) & No & None & Flexible bronchoscopy with net & 75 \\
\hline $\begin{array}{c}\text { Bredenoord } \\
\text { (10) }\end{array}$ & Yes & Cough & Cough & 65 \\
\hline Guy (1) & No & None & Rigid bronchoscopy with basket & 90 \\
\hline Depriest (2) & Yes & None & Flexible bronchoscopy with net & 90 \\
\hline Ding (6) & Yes & Cough & Bronchoscopy & 80 \\
\hline Ding (6) & Yes & Dyspnea & Cough & 88 \\
\hline Koulaouzidis (3) & Yes & None & Cough & 76 \\
\hline Pezzoli (8) & No & None & Cough & 82 \\
\hline Tabib (11) & Yes & Cough & Cough & 78 \\
\hline Sepher (12) & Yes & Cough & Rigid bronchoscopy with net & 67 \\
\hline
\end{tabular}

Risks for aspiration include underlying neurologic disease, elderly patients, and patient with previous difficulties with swallowing. Signs of capsule aspiration vary from asymptomatic to shortness of breath, cough, and tachypnea (1-12).

The capsule is a wirelesses, $11 \mathrm{~mm} \times 26 \mathrm{~mm}$ capsule with a miniature video camera, light emitting diodes, batteries, transmitter, and an antenna. It is slippery, nonbiodegradable, has plastic housing, and weighs less than 4 grams (13).

This case represents a rare, but important complication of wireless capsule endoscopy requiring evaluation and possible intervention. Although this complication is rare, it is likely we will see increasing frequency as capsule utilization increases. 


\section{References}

1. Guy T, Jouneau S, D'Halluin PN, Lena H. Asymptomatic bronchial aspiration of a video capsule. Interact Cardiovasc Thorac Surg. 2009;8(5):568-70. [CrossRef] [PubMed]

2. Depriest K, Wahla AS, Blair R, Fein B, Chin R Jr. Capsule endoscopy removal through flexible bronchoscopy. Respiration. 2010;79(5):421-4. [CrossRef] [PubMed]

3. Koulaouzidis A, Pendlebury J, Douglas S, Plevris JN. Aspiration of video capsule: rare but potentially life-threatening complication to include in your consent form. Am J Gastroenterol. 2009;104(6):1602-3. [CrossRef] [PubMed]

4. Choi HS, Kim JO, Kim HG, Lee TH, Kim WJ, Cho WY, Cho JY, Lee JS. A case of asymptomatic aspiration of a capsule endoscope with a successful resolution. Gut Liver. 2010;4(1):114-6. [CrossRef] [PubMed]

5. Buchkremer F, Herrmann T, Stremmel W. Mild respiratory distress after wireless capsule endoscopy. Gut. 2004;53(3):472. [CrossRef] [PubMed]

6. Ding NS, Hair C, De Cruz P, Watson J. Education and Imaging. Gastrointestinal: symptomatic bronchial aspiration of capsule endoscope - a significant complication. J Gastroenterol Hepatol. 2013;28(5):761. [CrossRef] [PubMed]

7. Nathan SR, Biernat L. Aspiration--an important complication of small-bowel video capsule endoscopy. Endoscopy. 2007;39 Suppl 1:E343. [CrossRef] [PubMed]

8. Pezzoli A, Fusetti N, Carella A, Gullini S. Asymptomatic bronchial aspiration and prolonged retention of a capsule endoscope: a case report. J Med Case Rep. 2011;5:341. [CrossRef] [PubMed]

9. Schneider AR, Hoepffner N, Rösch W, Caspary WF. Aspiration of an M2A capsule. Endoscopy. 2003;35(8):713. [CrossRef] [PubMed]

10. Bredenoord AJ, Stolk MF, Al-toma A.Tabib S, Fuller C, Daniels J, Lo SK. Unintentional video capsule bronchoscopy. Eur J Gastroenterol Hepatol. 2009;21(5):593. [CrossRef] [PubMed]

11. Tabib S, Fuller C, Daniels J, Lo SK.Sepehr A, Albers GC, Armstrong WB. Asymptomatic aspiration of a capsule endoscope. Gastrointest Endosc. 2004;60(5):845-8. [CrossRef] [PubMed]

12. Sepehr A, Albers GC, Armstrong WB. Aspiration of a capsule endoscope and description of a unique retrieval technique. Otolaryngol Head Neck Surg. 2007;137(6):965-6. [CrossRef] [PubMed]

13. Kelley SR, Lohr JM. Retained wireless video enteroscopy capsule: a case report and review of the literature. J Surg Educ. 2009;66(5):296-300. [CrossRef] [PubMed] 